\title{
Role of Hormones and Neuropeptides in IBS and other Gastrointestinal Disorders: Understanding Variability and Chrononutrition
}

\author{
D.W. Wilson ${ }^{1, *}$, A.P.S. Hungin ${ }^{1}$, J.H. Howse ${ }^{1}$, F. De Meester ${ }^{2}$, R.B. Singh ${ }^{3}$, A. Wilczynska ${ }^{2}$, \\ G. Cornelissen ${ }^{4}$ and F Halberg ${ }^{4}$ \\ ${ }^{1}$ School of Medicine and Health, Queen's Campus, Durham University, Stockton-on-Tees, TS17 6BH, UK \\ ${ }^{2}$ Tsim Tsoum Institute, Ul. Golebia 2, 31-007 Krakow, Poland \\ ${ }^{3}$ Halberg Hospital and Research Institute, IFTM University, Moradabad, India \\ ${ }^{4}$ Halberg Chronobiology Center, University of Minnesota, Minneapolis, Mn 55455, USA
}

\begin{abstract}
Mind-brain-body-gene framework, including the role of chrononutrition, is probably implicated in the genesis of functional gastrointestinal diseases (FGIDs). Emphasis was placed on psychosocial dysregulation, the bridging of the Cartesian Gap, and chronobiology viz. the way circadian and other rhythmic structures of the brain, e.g. suprachiasmatic nucleus, and gastrointestinal tract interact partially explaining the phrase "we are what and when we eat". Chronobiological concepts of strain and stress in the context of sensory pain and the time-qualified network of gut hormones and neuropeptides are discussed for melatonin, serotonin, ghrelin, leptin, vasoactive intestinal peptide, neuropeptide Y, orexins, and others. The Tsimtsoum evolutionary aspects of diet from Palaeolithic to modern man in the context of increased omega-3/omega- 6 fatty acid ratio reduces proinflammatory responses, important in pre-metabolic syndrome and cardiovascular disease, and protects against neuropsychic disorders possibly (FGIDs). Gut micro-organisms either affect the lumen (food substrates) and mucosa, where they reflect immunological, metabolic and physiologic function and importance of these two ecosystems. The interaction between enteric and autonomic systems and associated regulatory effects on proliferative and secretary epithelial dynamics and optimization of permeability for food nutrients and possible modulation of inflammation is an active area of research. In summary, this paper has focussed on the need to understand the multifarious aspects of biological and environmental variability, principally hormones and neuropeptides, in the possible genesis of (FGIDs).
\end{abstract}

Keywords: Irritable Bowel Syndrome, Chronobiology, Polyunsaturated Fatty Acids, Tsim Tsoum Concept, Commensal Biota, Cartesian Gap.

\section{INTRODUCTION}

Clinicians are faced with a considerable cost-consuming prevalence of functional problems, dominating perhaps half of all U.K. National Health Service (NHS) primary and secondary care consultations [1], of which functional gastrointestinal disorders (FGIDs), e.g. Irritable Bowel Syndrome (IBS) is one example. Although classified by the Rome III criteria [2, 3], the term 'functional' is scientifically not well defined and even a misnomer when applied to FGID [4]. One definition [5] referred to "a variable combination of chronic or recurrent symptoms not explained by structural or biochemical abnormalities", but explanatory models are simply not available since they must take account of overlapping clinical disorders, if these have a well-defined basis, and, i.a., temporal and physiological specificity [4]. Although IBS, the prototype 'functional' bowel disorder, was reported nearly two centuries ago [6] it was Engel [7]

*Address correspondence to this author at the School of Medicine and Health, Queen's Campus, Durham University, Stockton-on-Tees, TS17 6BH, UK; Tel: +44 (0) 19133 40825; Fax: + 44 (0) 19133 40793;

E-mail: d.w.wilson@durham.ac.uk who suggested a multi-level biopsychosocial framework operating for this disorder i.e. a mind-body framework (q.v. Fig. 1). However, it seems that nutrient content of foods consumed may be important in the pathogenesis of IBS.

Substantial evidence has implicated a psychological component in functional disorders [8], such as anxiety, depression, former abuse, and a high response to placebo therapy but none of these, alone or in combination, is a marker of such disorders. Hungin and his colleagues have suggested a role for the mind and brain-body interactions [9] in Inflammatory Bowel Disease (IBD) and Hungin herein has extended this concept to IBS. Thus, for example, hormone action between brain and gut [10], complemented by haemodynamic studies using fMRI (functional magnetic resonance imaging) may lead to a greater understanding of the brain, through blood-oxygen (oxyhaemoglobin) response to neural activity $[11,12]$, if temporally adequate. The initiation and development of IBS and other GI disorders themselves complemented by electrophysiological studies of afferent/efferent neural connections in GI tissue to understand, i.a., visceral hypersensitivity [13] are still 


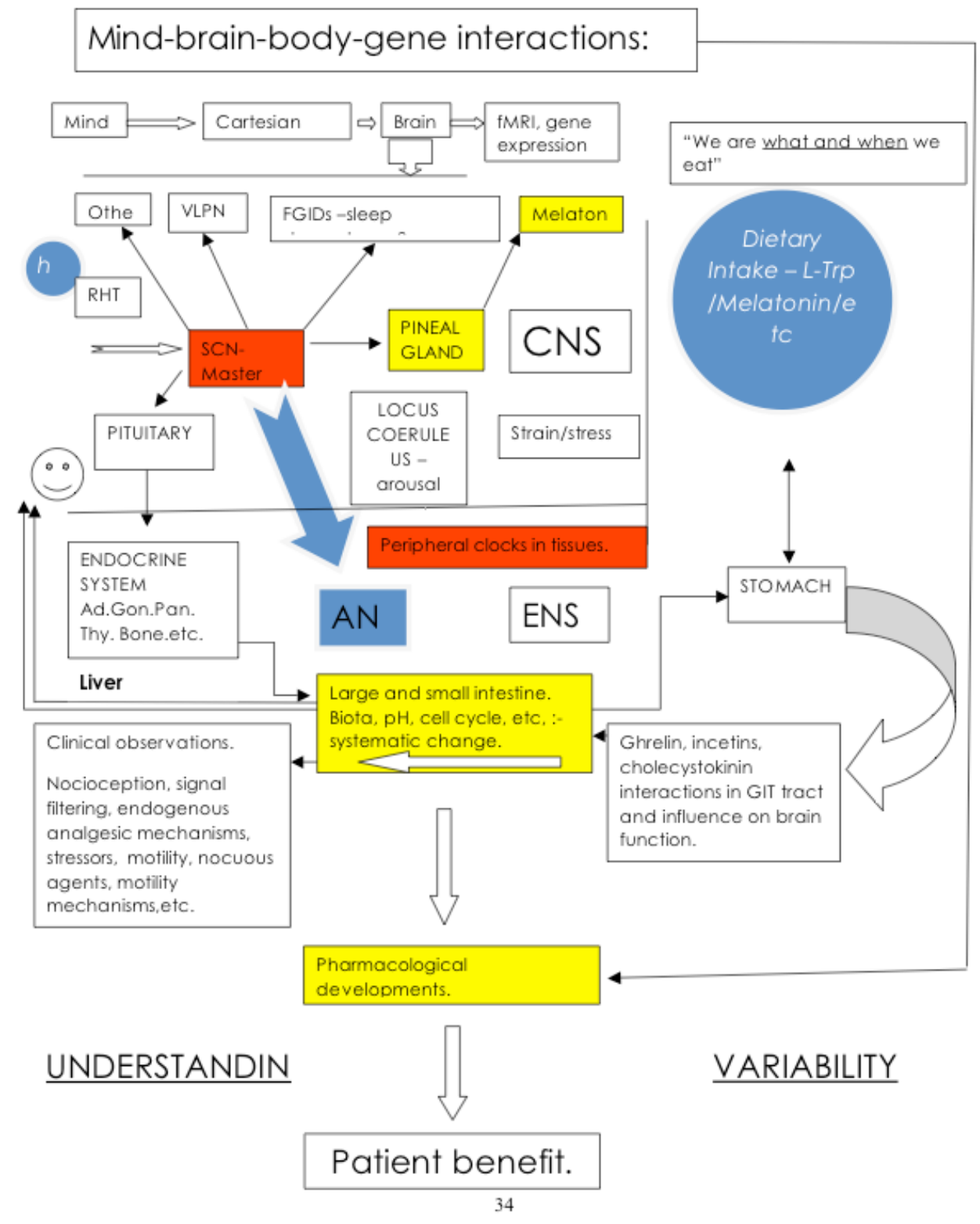

Fig. (1). Understanding mind-brain-body interactions through systematic appraisal of clinical, chronobiological, endocrinological, and environment factors in FGIDs with emphasis on melatonin and serototin.

needed. Sheehan et al., [14] pooled imaging information on IBS, and control, subjects and higher activity was found in the former group but there was considerable heterogeneity in regional activity in the brain obtained from the literature. However, since fMRI is highly multidisciplinary and a technically and medico-scientific evolving procedure, it is perhaps premature to implicate the amygdala (albeit in the rat), or any other structure in relation to visceral pain [15] until more work is carried out.

Sensory afferent vagal information, e.g. possible amino acid signals [16] or polyunsaturated fatty acids [17], may also be important and related not only to the dietary metabolites but also reflecting the 'so-called commensal' microbiota signalling toxicity or nutritional information to the brain. Now, after 'The Road to Rome'[18], in this paper, i.a., the chronobiological perspective has been introduced in trying to explain factors involved in the initiation and development of FGIDs [19].

\section{MIND-BRAIN-BODY-GENE FRAMEWORK}

In this paper, we consider the mind-brain-body-gene framework (q.v. schema of Fig. 1) in which the putative genesis of IBS and allied parts of this spectrum of diseases is initiated, developed, diagnosed and treated. Later in the paper evolution [20] and early events in the development of humans is explored for the development of a review framework to understand the possible origins of FGIDs. There is need to indicate role of Western diet and soluble and insoluble dietary fiber and probiotics in the pathogenesis of IBS. It seems that both the agents can stimulate brain via gut hormones- vagal traffic and modulate the bowel function causing relief in symptoms of IBS.

\section{The Mind}

From a secular position, the mind is such that "a person's mental activities are entirely due to the behaviour of nerve 
cells, glial cells, and the atoms [21], ions, and molecules that make them up and influence them" [22]. Clearly, Nurse's remarks [23] are relevant as the neural sciences and psychiatry require a "rapprochement that seeks a deeper understanding of the biological basis of behaviour," [24]. How functional bowel disorder is made manifest by psychosocial dysregulation of the central nervous system enteral nervous system linkage is difficult to identify mechanistically. However, clinical and experimental trials with refined foods vs. Mediterranean foods can enhance our understanding upon the role of nutrients and foods in understanding the mechanism of mind-brain-gene-body interactions in IBS.

Perhaps in the future we need to think about new models about how we bridge the Cartesian Gap and think of mindbrain-body-gene systems. Using an "in silico" approach [25, 26], it may be possible to build a model for gastrointestinal diseases/syndromes that, where appropriate, systematically embraces psychotherapy [27] and the application of functional magnetic resonance imaging [28] to indicate brain localization [29], though care must be taken in interpreting whether this IBS pain is really related to visceral hypersensitivity and/or brain processing. Thence to identify activity-dependent gene expressions (using a human brain atlas of brain expression (q.v. Allen Brain Mouse Atlas of Gene Expression ("http://www.brainmap.org; accessed $10^{\text {th }}$ July 2011)) using DNA microarrays [30]. When more information is created for humans one may expect to see of the order of $80 \%$ of genes expressed leading to activity-dependent brain plasticity (synaptoand neuro-genesis) using a connectivity map [31], and finally resulting in a creative healing experience that the psychotherapy brings about or otherwise. The "in silico" method uses the concept of information processing models, the information being in life sciences rather than 'wetware' but research indicates that the Cartesian Gap may not exist. The effect of psychotherapy on mind-brain-gut function appears to be under influence of nutrients. This century will probably be renowned for this type and parallel/other types of information processing in health and disease but meanwhile most researchers will focus on more traditional networks of mind-brain-body interactions. Another frontier, viz. gene therapy, has gained some momentum but, simply put, weaving genes into genetic material to effect therapy, despite considerable international effort, is still in its infancy [32].

\section{CHRONOBIOLOGY}

There are multifarious chronobiological actions and interactions that may be implicated in the genesis of FGIDs and other GI disorders. It is the suprachiasmatic nucleus $(\mathrm{SCN})$ that is the pace-setter for biological rhythms, e.g. circadian, that network with tissue CLOCK genes [33] in various parts in the body such as the liver, and small and large intestine. The mechanisms as to how these interact, viz. brain, GIT, muscle are not fully elucidated and are an active area of research [34]. Firstly, focussing on melatonin [35], consideration should be given to the two major components of melatonin secretion, viz. that of the pineal gland which is maximal during darkness when the electrical input from the suprachiasmatic nucleus ( $\mathrm{SCN}$ ) is lowest, and gut synthesis from dietary L-tryptophan and other dietary components
[36]. It appears that most organs have an endogenous circadian rhythm [37-39], including the murine gastrointestinal tract [40, 41] and there are many other examples [42]. These rhythms are influenced by the time of sleep onset and input from the SCN, including those of the cell-cycle $e . g$. along the gastrointestinal tract. There are other circadian clock genes in other parts of the brain [43]. It is possible, that there is a progression from health and disease in the timing of G1, S, M and G2 phases [44], involving the cyclins and cyclin-dependent kinases where they elicit their regulatory action in the appropriate bound-pair form. The mechanisms are complex and are reviewed by Nurse [45] in his Nobel Lecture, and also involve cell-cycle checkpoint genes and the mammalian Timeless protein. Thus there are at least two synchronised systems, the circadian system (for nutrition q.v. Singh [46-48] and the cell-cycle one coupled to the other by putatively serial or direct coupling [49].

In relation to dietary sources of melatonin and other constituents, 'we are what we eat [50]' but perhaps more relevant here is 'when we eat [51]' which in turn raises questions about GI diseases in shift-workers [52] and that IBS may be a manifestation of dietary timing and maladjustment of body clocks. Superposed on, for example, 'what and when' are the 'hot' and 'cold' preferences between night and day workers and gastric disorders [53] such eating habits are often associated with shift workers [54]. It has been reported that IBS is more prevalent in shift workers [55] and even more so in rotating shifts [56]. Chronobiology and chrononutrition are discussed further (vide infra; Section entitled 'Gut hormones and neuropeptides.') but from multifarious perspectives, especially chrononutrition, the work of the late 'Larry' Scheving [57-59] is relevant.

Work on cell population kinetics estimated from tritiated thymidine and ${ }^{32} \mathrm{P}$ inorganic phosphate incorporation into DNA by murine epithelia prompted Quastler and Sherman [60] to make understandably a number of assumptions. These included, i.a., i) that the epithelium was in a steady state and thus the average length of time spent by cells in a particular compartment and size of compartment would be related and ii) the length of time spent in one compartment was independent of another; such work was later substantially developed by Donaghey [61, 62]. Donaghey [63] used multistate models with various probability distribution functions to simulate the movement and proliferation of cells through their generative cycle, and subsequent use for cancer therapy of interest to Wilson and Griffiths [64], but not chronotherapy. It was Rubin [59] using flow cytometry, and Scheving [58] as cited by Cornelissen [65] which clearly demonstrated murine rhythmicity in DNA synthesis and opened up potential areas of research such that feeding schedules may be able to manipulate specific growth or regulatory factors possibly implicated in gastrointestinal disorders. Fasting for $24 \mathrm{~h}$ leading to a statistically significant reduction in circadian DNA synthesis in ten regions of the murine gut was explored with the goal of establishing any impact these may have e.g. cancer chronotherapy. Whereas a statistically significant difference due to fasting was not along the entire gut e.g. not in the colon but in the caecum, data demonstrated the need to examine cell proliferation in fasting and on various chrononutritional meal schedules and therefore possibly 
any impact this may have on functional gastrointestinal disease.

\section{Concepts of Stress, Strain, Brain and Pain}

Functional GI disorders account for $c 12 \%$ of patients in primary care and $c 40 \%$ examined in general GI practice and in the USA comprise about 3 million physician visits per year. The organic pathology of functional GI disorders is not well defined compared to other GI diseases (q.v. Rome III definition (vide supra) of e.g. gastroesophageal reflux disease (GORD) and Inflammatory Bowel Disease); and the use of discriminant function analysis [66] to differentiate IBS from other GI disorders. Such disorders probably involve an integrated process between 'mind \& brain' (vide infra) in which the human body is subject to an internal or external temporal stimulus (acute, chronic, intermittent) of varying magnitude and source (physical, emotional and mental) with consequent physiological and behavioural changes that may/may not be accommodated by the patient. Chronobiological adaptation (strain: when rhythms (networks) are controlled and accounted for) or otherwise (stress: not accounted for) in which combinations of the elements of pain (sensory, affective, autonomic, motor) may form the feeling of unease but which may be absent (alarm bell absent when pain expected; alarm bell rings when there is no fire; surgical procedures do not stop pain completely). Consequently, nocioception, signal filtering, endogenous analgesia mechanisms, etc., should be considered in clinical patient management whencesoever possible.

Indeed, subjects differ in their sensory detection and pain perspective thresholds and pain tolerance which may have clinical implications in GI disease management. Ethnicity, shaped through culture, and personality may affect pain perception: though pain experience can affect personality. In post-uterine life, some of the risk factors for functional GI disorders generally include psychosocial and lifestyle factors and other stressors. Stress, using for convenience the definition of Hans Selye [67], "a syndrome produced by diverse nocuous agents" with behavioural and physiological responses, affects, inter alia, the hypothalamic- pituitary axis, the immune system and the sympathetic adrenal medullary system. Therefore, patients with IBS may exhibit temporal symptoms of perceived pain depending on culture, personality and other factors, such as timing of dietary intake.

\section{Biochemistry - Mind and Body}

The age of biology is rapidly changing from simply identifying biochemical messengers (though discoveries are still essential) and 'discovering' modes of action, to, in the $21^{\text {st }}$ century, understanding information processing [23], Sir Paul Nurse's Opening Address, Society of Biology, viz. "We need to follow the information. Our objective in biological research needs to be the description of how living organisms work in terms of managing information in the complex systems of cells, organs, organisms, populations, biosphere and evolution")] involved in multifarious actions and interactions with an array of mechanisms. For example, hormones, growth factors, cytokines, all appear to be involved in the immune, ENS and CNS systems with respect to the classical hormone, melatonin, and its putative rôle in the genesis or development of functional GI disorders. In order to clarify the different characteristics between each of these three classes of generally, but not exclusively, extracellular signalling molecules, which are largely proteins, the following guidelines are adopted [68]. Growth factors (e.g. epidermal growth factor (EGF) and Transforming Growth Factor - alpha (TGF- $\alpha$ ) appear to be largely constitutive and targeted generally toward nonhaematopoietic cells whereas cytokines, which may share redundancy of action, exhibit pleiotrophy- multiple target cells and actions (e.g. interleukins, interferons, tumour necrosis factors, chemokines and transforming factor- $\beta$ ). It is difficult to escape that hormones ([69]; secretin) are the specific internal secretions of the endocrine glands that act at distant sites e.g. steroids through non-genomic and genomic mechanisms, though such definitions are imprecise q.v. melatonin (vide infra). From an evolution perspective [(e.g. tubular organisms -modern day Ascidian - genomic sequencing- homologies, Ciona Intestinalis [70, 71]; divergence from vertebrates $500 \mathrm{Ma})$ ).] the head (increasing complexity of the evolving organisms) and ENS (forerunner) brains may have developed separately one capturing and using sensory stimulus e.g. light, and the other using food stimuli.

\section{GUT HORMONES AND NEUROPEPTIDES}

The major thrust of argument for this report is directed largely towards the production and mechanism of action of melatonin and precursors, and of neuropeptides and gut hormones that may be involved in IBS e.g. ghrelin - the appetitive hormone, leptin, cholecystokinin, incretins, fatty acid metabolism and brain-derived neurotrophic factor (BDNF) which are internally and externally driven. As more information is becoming available the proliferative and secretory epithelial dynamics and its regulatory mechanisms, mediated through the enteric/autonomic nervous system (q.v. Fig. 1) and neuropeptide (VIP) and hormone modulators (ghrelin) of inflammation, seem to optimize permeability for uptake of food nutrients. Whilst in concert they appear to guard against luminal antigens with immune cell activation mechanisms which is adjudged important [72, 73]. Ghrelin receptors (G-protein coupled) are expressed throughout most of the gastrointestinal tract on vagal afferent endings [74], and reduces the sensitivity of these endings [75].

Ghrelin receptors are also present in the arcuate nucleus and influence growth hormone secretion through activation of the growth hormone secretagogue-receptor [76], and peak following sleep as does leptin and melatonin. Ghrelin was the first described orexigenic gut-derived peptide and controls gastric motility [77] as does leptin [78] and many other neuropeptides acting on vagal afferent endings in the gastrointestinal tract. In patients with irritable bowel syndrome, leptin, on the other hand, has half the plasma concentration than controls (7.41 and $19.33 \mathrm{ng} / \mathrm{mL}$ : Semnani et al., [79]. Reports of higher concentrations of plasma cholecystokinin and sigmoid tissue content in IBS $c f$ with controls has been reported [80], similarly for vasoactive intestinal peptide (VIP; [80] and the reverse was true with lower statistical significance for Neuropeptide $\mathrm{Y}(\mathrm{NpY})$. How are all these observations to be interpreted? 
We have evidence to suggest that interacting hormones or neuropeptides should be time qualified, not only individually but also as interacting networks [23] so that feedsideward effects [81] may be recognized should they exist, and this is apart from the observation that plasma levels are not necessarily an indicator of system pathology [82].

However, one of the incretins, a group of gastrointestinal hormones produced in the gut, viz. GLP-1, derived from L-cells from totipotent stem cells, has been shown to be elevated in response to fat and carbohydrate and is implicated in motility, glycaemic control and stomach emptying. Furthermore this incretin was shown in rats to increase the firing rate in the afferent vagal nerves [83, 84] and affect the satiety centres in the brain. Its ROSE-010 analogue, formed by substituting a valine amino acid for aniline [84], was shown to inhibit stomach empting, was motility-inhibiting and provided pain relief in patients with IBS. No such study would be complete without discussion on fat and fatty acid-CoA $[85,86]$ and carbohydrate or indeed the immune system which may be defective in IBS and some other functional gastrointestinal disorders.

Regulated by ghrelin [87, 88] /hypocretins [89], orexins in neurons of the lateral hypothalamus regulate feeding [87] have a central effect on gastrointestinal function mediated through the autonomic central nervous system [90]. These latter authors consider a lack of oroxin activity in the brain may be implicated in gastrointestinal disorders. Furthermore, therapeutic control orexinergic projection may lead to treatment for same. Paraphrased, orexins affect: gastric secretion [91]; are implicated in sleep-wake/depression/ gastrointestinal disorders; gastroprotection (orexin A), possibly mediated through NO synthase activity that networks with the orexin neurons in the dorsal motor nucleus and possibly affects vagal tone; etc., as reviewed [90]. It is clear from the literature $[65,90,92]$ that much more chronome mapping, selective antagonists, and other methodologies are needed to progress our understanding of brain-gastrointestinal interacting 'endocrine' [74] network functions and their diseases and treatment in the human.

Returning to the importance of time-qualified sampling of neuropeptides by Halberg's team, viz. VIP, NpY and a neuropeptide Subtance P (SP); these were measured in the venous blood drawn hourly from an antecubital vein of clinically healthy adults aged between $23 \mathrm{y}$ and $31 \mathrm{y}$ (3 females and 17 males) using a non-thrombogenic catheter. Two groups were formed and each was studied in a nosocomial environment for $25 \mathrm{~h}$ but with different start times, one group came into the hospital at $18.00 \mathrm{~h}$ and the other group came in at 07.00. Using cortisol as an internal marker of circadian synchrony, the profiles of each hormone displayed different characteristics as documented by Lockinger [92]. Paraphrased, it was demonstrated that the circadian patterns for these neuropeptides depended on the start time of blood sampling. The wave form of VIP being circadian (population Cosinor analysis [93]) though not demonstrated in all single Cosinor analyses, and also had a 3h component. However, SP and NpY, which both exhibit vasodilatation properties, displayed plasma circaoctohoran patterns. Thus clinical studies of these hormones should consider very carefully the sampling schedule which includes the start time. VIP (28 AA) [AA represents amino acid residues.] is present in the central nervous system and the gastrointestinal tract and i.a. is implicated in melatonin and pituitary hormone secretion; SP (11 AA) has an important pain perception function involving transmission of same to the central nervous system; NpY (36AA) is i.a. involved in feeding, sympathetic coordination of cardiovascular function (exhibiting vasoconstriction) and anxiety/mind properties, a possible component in IBS. Thus chronomes (time structures) should be mapped, i.a., for these neuropeptides and other hormones, otherwise 'Trojan' results and conclusions may ensue.

This report indicated that IBS was associated with dysfunctional immunological response to bacteria; was associated with a defective gut epithelial barrier, with mucosal dysfunction and increased mucosal permeability; had impaired motility and was often associated with psychological factors, making mind-body (e.g. GIT) interactions key issues for research. Another candidate neuropeptide that has been investigated in brain and gut is neuropeptide S (NPS; 20AA) [94], not to be confused with Substance P, and its orphan G-protein-linked receptor NPSR1. NPS is found, for example, in the parabracial nucleus and locus coeruleus of the brain. Its receptor is also found in the brain where the NPSR1-NPS system can modulate stress in the paraventricular hypothalamic nucleus, hippocampus and amygdaloidal complex, and is also possibly implicated in the regulation of pain. Such a receptor-neurotransmitter system is present in the gut in enteroendocrine cells and NPS has been found to express in vitro stimulation of CCK, ghrelin, VIP, etc., and particularly somatostatin.

\section{Polyunsaturated Fatty Acids}

There is considerable interest in the omega-3/omega- 6 fatty acid ratios from a pro-inflammatory perspective in respect to metabolic syndrome and cardiovascular disease [95-100] where omega-3 fatty acids, through a Mediterranean diet, perhaps more akin to diet of early man $[101,102]$ have been reported to also protect against neuropsychic disorders [96]. Clarke et al., [17] have focussed attention on circulating polyunsaturated acids and their possible role in immune-related disorders and found elevated concentrations of arachidonic acids in patients with IBS. It is interesting that this diet, in accord with the TsimTsoum concept $[103,104]$. The TsimTsoum Concept is the Western evidence-based approach to the Eastern observation-based YinYang Concept that human (memes) interact with Nature (genes) in mutually influencing ways, yet both memes and genes pursue their independent evolutionary thrust at their own pace leading to conflicts of interest. Modern man must possibly combine modern memes and ancient genes. This leads to ever more stress-strain psychosomatic states that must be accommodated at tissue level-i.e. "The Tissue is The Issue". Modern chronic degenerative diseases can be studied from that refreshing mind-body perspective [103].

\section{MELATONIN}

One candidate hormone that merits further study is melatonin [105-108] produced by the pineal gland (site of 
the (unpaired) soul/mind; Descartes [109, 110] and the gut, (from its precursor serotonin [111] derived from dietary L-tryptophan), which has been reported to influence gastrointestinal motility and sensation. Melatonin reportedly attenuates abdominal pain and increases the rectal pain threshold in patients with IBS with sleep disturbances [112]. However, one has to be mindful that melatonin can come from various sources, which is not generally appreciated, e.g. from plants that naturally comprise foodstuffs and 'exogenously' in processed food commodities/health supplements. It is secreted from the pineal gland driven by retinal photic stimuli (q.v. early work in the frog [113] neurally projected to the $\mathrm{SCN}$, and synthesis in the gut.

Primarily we are interested, in the possible influence of melatonin on FGIDs, from a mind-body perspective and as a consequence now explore important relevant concepts.

In the first instance, light impulses which signal the time of day and season (position relative to the Sun) through the SCN and thence melatonin is endogenously synthesised in the pineal gland and then secreted finally into the general circulation. Secondly, melatonin is a constituent of beverages and edible plant material [114] and endogenously secreted into the gastrointestinal tract [115] from precursors such as serotonin and L-tryptophan. Particular importance is given to the role that circadian cycles (e.g. wake/sleep, cell proliferation) may have on the prevalence of the disease arising from shift-work, blindness, sleep-related syndromes, pathophysiological and psycho-social factors, and subsequent management strategies and how these may be used for patient benefit.

\section{Melatonin in Plants: Foodstuff and Beverage}

Human tissues such as the gastrointestinal tract are exposed to melatonin of plant, animal, and 'exogenous' origin (beverage industry: Beer [116]; human milk [117, 118]. The possible influence of melatonin on FGID is now explored.

Reminiscent of oestrogens/phyto-oestrogens [119], melatonin, once thought to be solely of pineal origin has been found in algae, fungus, bacteria and plants [120-127], particularly in the Poaceae (Festuca (cereals: rice, oats, and maize)), and medicinal plants [128], and is produced in a variety of animal tissues such as the pineal gland, skin, bone marrow cells, blood platelets, Harderian glands, and the gastrointestinal tract (oral cavity, oesophagus, stomach, duodenum, etc). Though caution must be expressed in drawing biochemical meaningful comparisons between melatonin in the plant and animal that may be important in a human clinical gastrointestinal setting, none-the-less some parallels are indicated. In the plant world, it appears protective against oxidative stress $[125,129,130]$, and is a chronobiological information provider [131-134], (attenuator of apoptosis)). In edible and other plants consumed by humans, the melatonin and serotonin precursors appear to be derived from L-tryptophan though exact biochemical sequences are, as yet, largely unknown, and some precursors, or even the hormone, may be derived by root absorption from the soil [135, 136] probably as a result of soil organisms $[137,138]$.

\section{Melatonin Driven by Light and the SCN}

Although speculative, it is possible that disruption of circadian system interactions with the gastrointestinal epithelial tissue [139], influenced by an external environment such as food ingestion, may adversely affect gastrointestinal function. Clearly the internal circadian clock mechanism is necessary so that internal coordination can take place between metabolic processes and the timing of ingestion: a cycle of activity (photoperiod) and repair (scotoperiod). The SCN monitors the global position relative to the sun, through light input of a certain intensity and frequency range via retinal melanopsin-containing ganglion cells $[140,141]$ which extend along the retinohypothalamic tract [142] where glutamate is released at synapses activating a signalling mechanism leading to the phosphorylation of cyclic adenosine monophosphate (cAMP) response elementbinding protein $(\mathrm{CREB})$ that result in the expression of Perl and Per2 genes [143, 144]. Delayed or advanced phases of such activity may influence sleep and metabolic processes if these circadian rhythms are desynchronised.

To emphasis this point [145] Kalsbeek et al., showed that the SCN a) connects to the sleep regulation centre, viz. ventrolateral preoptic nucleus, b) the pineal gland, which is a major secretor of the dark hormone, melatonin, c) thermoregulatory regions, e.g. median preoptic region, d) the feeding area e.g. dorsomedial hypothalamus and e) the hormone-secretory areas of the paraventricular nucleus. This circadian clock mechanism of the SCN does have an important role in mood disorders [146] and one is also conscious of the psychological risk factors associated with patients with FGIDs [8].

From the SCN, fibres project to the paraventricular nuclei and thence, via the spinal cord to the largest of the cervical ganglion (superior) as part of the sympathetic nervous system and from there to the pineal gland: denervation of which obliterates its circadian rhythmicity. The interactions between clock, cell cycle and metabolism may be instrumental in the development of FGIDs and some other GI disorders, depending on the degree of desynchrony, and may be associated with mood and sleep deprivation.

\section{PINEAL GLAND AND MELATONIN SECRETION}

There have been many classical treatises on mind and soul, perhaps beginning with the Legendary Yellow Emperor (2697-2597 B.C.) [147] but it is the one by René Descartes $(109,110)$ on the pineal gland, 'emotion' and 'animal spirits (anima; res cogitans); mind)' and 'Cartesian Gap' that is considered of some relevance to the topic of this paper, viz. melatonin production. It is the purport of this paper to implicate the pineal gland, and gastrointestinal cytokines, growth factors and hormones in the development of FGIDs.

In humans and other mammals, melatonin is synthesized in the pineal gland arising from rhythmic transcription, predominantly in the scotophase [148] (as in some plants $[149,150])$, from circulating L-tryptophan to serotonin by the pinealocytes subsequently, using several enzymes, viz. tryptophan 5-monoxygenase/ hydroxylase, followed by a decarboxylating enzyme (EC 4.1.1.28.) to give serotonin which is followed by another enzymatic reaction viz. 5-HT $\mathrm{N}$-acetyltransferase (AANAT; (EC 2.3.1.5.); Klein [151]) to 
produce $\mathrm{N}$-acetyl serotonin, and then hydroxyindole-Omethyltransferase (HIOMT; EC 2.1.1.4.) acts to form melatonin. In identifying the interactions of melatonin on IBS and related disorders, the physiological sequence of melatonin needs to be established, in the overall context of melatonin networks, and patient circadian exposure arising from the pineal, hypothalamus, anterior pituitary and then with other contributory sources such as plasma. Zeman [19] demonstrated in Wistar rats, that indeed the acrophases of the circadian rhythm for pineal, hypothalamus, plasma and duodenum occurred in the dark period more than $12 \mathrm{~h}$ after hours-after-lights-on (HALO) and generally that is the lead order. The content of the hypothalamus was very low compared to plasma whereas plasma concentrations were about1/10 of the pineal gland.

\section{Gastrointestinal Melatonin Secretion and Interaction with Serotonin}

Melatonin secretion by the gastrointestinal tract has been known for over 3 decades [152] and analytically validated, and the main precursor is dietary L-tryptophan: the main cells responsible for production appear to be the serotoninrich enteroendocrine cells [153]. The role of the GIT is apparent when plasma concentrations of melatonin were found to be higher (and dose dependent) when tryptophan was given orally compared with a similar dose intraperitoneally and that this dropped on portal vein ligation otherwise higher than plasma. Pineal melatonin does not seem to exhibit any dose dependent food intake relationships. Autoradiographic studies with labelled 2-( ${ }^{125} \mathrm{I}-$ melatonin) demonstrated that the mind-GIT interaction is operative in the feedback on food uptake, and it is the periodicity of food intake that governs the rates of lipophilic diffusion and more specific membrane receptor mechanisms.

However, we must consider the potential role of serotonin, having fulfilled all the criteria for a neurotransmitter, synthesised from tryptophan in the enterochromaffin cells (EC) that line the gastrointestinal tract, and melatonin, as potential antagonists which is released from EC apparently dependent on feeding periodicity [154]. Serotonin, like melatonon is found in unicellular organisms, plants and animals, and has multifarious functions in the mammalian CNS where it acts as such in muscle contraction, sleep, and mood and is concerned with appetite and food digestion. Produced in the GIT mainly within A(amine)PU (precursor uptake) $\mathrm{D}$ (decarboxylase) cells [155], both hormones appear to have a role in the stimulation and inhibition of the myoelectric activity of the GIT. These influence bowel motility acting through cyclic myoelectropotentials (slow wave and spike), expressed and located in the myoelectro-migrating complex, that itself is under basic electrical slow wave rhythmic control of interstitial Cajal pacesetter cells. These cells are under the influence of internal and external autonomic nerves (canine: [156]).

It would appear that the inhibition of bowel motility by melatonin is not only dose dependant but endogenous melatonin may operate on pre- and post-prandial bowel motility at night. Of relevance, is that both melatonin and serotonin seem to be involved in hypersensitivity and pain conductance in mice [157] and that melatonin treatment alleviates pain in IBS [158] and (vide supra [112]) acting along the brain-gut axis [159]. Melatonin has also been implicated in cluster headaches, lower nocturnal secretion (advanced phased) melatonin, as reported by Chazot et al., [160] but cause-effect inferences must be guarded ones. However, a logical explanation could be sleep management given that melatonin is sometimes referred to as the 'dark' or 'sleep' hormone. Indeed Mozaffari et al., [161] have reviewed eight clinical trials and conclude that melatonin decreases abdominal pain and improves the IBS symptom score but caution must also be expressed concerning the sometimes 3-fold increase in placebo effect (compared with placebo arms for other treatments) as reported by one of us (APSH) [162] (but this high effect generally decreases on length of follow-up).

\section{Intestinal Microbiota and Microflora}

It would seem not irrational to propose that gut bacteria exert some influence on the genesis or development of IBS and other GI disorders. Collectively gut bacterial cells comprise many trillions of cells, have an aggregated gene pool approximately 100 fold that of the human genome, are $60 \%$ of dry faecal weight, about 500 species of organisms [163] of which about 40 dominate, mainly anaerobic. Bacterial cells have already been implicated, acting through the immune system, producing short chain fatty acids, and hence preventing IBD e.g. Crohn's disease. However, how may these organisms control their integration and population dynamics, and do they produce hormones or influence afferent or efferent neurotransmission? Broadly, the gut micro-organisms comprise bacteria mainly associated with the lumen (food substrates) and mucosa (epithelium) that reflect immunological, metabolic and physiological function [164]. Gut physiological and metabolic processes and microflora exhibit rhythms of many kinds such as gastric acid secretion, gastric emptying, DNA synthesis ([57] in the mouse), digestive enzyme expression, activity along the crypt-villus axis, colonic motility [165] and in gut bacteria [136]. The dynamic interactions of these two ecosystems is an active area of research and the variability of water in the GIT and the differences in populations has been/is exploited using pro-drugs which are inactive until they reach the colon whence the active drug is released by colonic bacteria or else use the $\mathrm{pH}$ intestinal gradient [166]. Dietary glycated protein can change the harm/protection bacterial milieu such that it is exacerbated in ulcerative colitus [167]. Indeed dietary constituents such as polysaccharides avoid, somewhat, metabolism in the small intestine until the heavy bacterial ecosystem is reached which is an area of interest to the pharmaceutical industry such as COLAL-PRED an amylaseethyl cellulose sprayed tablet of prednisone sodium metasulfabenzoate, the bioavailability indicated by plasma levels of the drug. It is by understanding variability in human subjects, e.g. increasing gut microflora from proximal small bowel to ileum [168, 169], through the science of chronobiology, that variability may be exploited for chronotherapy.

\section{Evolution}

There has been relatively little change in DNA sequences during and since the lower Palaeolithic period (c2.5Ma $0.2 \mathrm{Ma}$ ) ('period' is used here to refer to stages in human 
cultural development or indeed very much longer [170, 171] but more obviously there have been major developments in man since c0.045Ma, viz. the upper Palaeolithic period [170] but this has been through regulatory mechanisms of gene expression. However, a feature of human development has been a population expansion which has led to human diaspora being exposed to more extremes of environment and consequently changing diets, the most noticeable of which has been in modern peri- and post industrial revolution times. The timing and extent of change will depend on global location and climatic conditions. In the evolution of modern man, e.g. the Fuegans, in-breeding and isolation may lead to disappearance of protective alleles because they are no longer exposed to any threatening agent. Adaption to diet is without doubt the main reason why man was able to live in so many diverse conditions being able to eat a wide variety of foods e.g. fish, birds, mammals, roots, nuts, leaves and fruit, etc. Even so, some peoples have difficulties (e.g. indigestibility of milk by native Australians, some Chinese and West and Central Africans $c f$. Europeans) due to impairment of lactase synthesis. Although there is some confounding of lactate mal-digesters and those with IBS, it is possible that 'civilization' differences exist [172] and one possible treatment is dietary lactose restriction [173]. Of possible relevance to GI disorders is that it is believed that the rapid increase in such diseases observed today may be due to the regulatory mechanisms not being able to adequately cope with such a dramatic recent change in diet [174]. Notably, there has been a marked increase in the omega-6/omega-3 ratio, in some Western countries, compared to that surmised from archaeological information and anthropological studies on carnivory and carbohydrate consumption in "pre-agricultural" times. The hypothesis is that a return to Palaeolithic man's generalised diet [101] may lead to a reduction in many chronic diseases such as Metabolic Syndrome and possibly IBS and related disorders: an increase in dietary omega- 3 being one candidate potential solution. As an aside it is important to consider that human organs and tissue may have vestiges in common with coevolutionary organs, e.g. ultradian rhythms in yeast and cardiomycetes [175] which are also important in heart failure mechanisms.

\section{Gastrulation}

As a prelude to implicating chronobiology in the genesis of IBS, and its development and treatment, it is conceivable, that IBS [(with its Central and Enteric Nervous Systems generating mind-body interactions (and characteristics such as pain/temporal symptoms/psychosocial history/high placebo response/sleep disorder))] e.g. mediated through the vagus nerve, may have their origin in gastrulation [176]. This is when there is a major reorganization of cells into three layers within the embryo from which organogenesis develop, and many organs and tissues will have both similar and, more obviously, dissimilar biochemical properties. Similarly, in principle, this may be the case for other functional disorders.

Briefly these three layers are described. It is appropriate to consider the pre- and post- natal neurodevelopment of each of three 'brains' [(head: central nervous system (CNS) in cranial cavity.); (immune system: a mobile lymphoid/ leukocyte system.); and (ENS: enteric nervous system.)] from primordia to adulthood because many GI disorders may have their origins in utero and are manifested in adulthood. The question this raises is which brain is 'king'? Using information based largely on non-primate mammals, at gastrulation, there is a primitive gut (archenteron) comprising an ectoderm, mesoderm and entoderm. The ectoderm undergoes neural induction and the formation of a neural plate is accomplished by proteins (e.g. activation of receptors for tyrosine kinases, inhibition of transforming growth factor- $\beta$ ) from organizer tissue. This leads to the development of the neural crest and thence histogenetic regionalization of the CNS occurs e.g. cerebral cortex, thalamus, cerebellum, etc. Separately the migration of cells form the ENS which becomes connected to the CNS by growing axons (filopodia seeking chemoattractants) that establish a scaffold for fasciculation and subsequent processes leading ultimately, inter alia, to the vagus nerve. The entoderm contain cells that lead to the lining of the oesophagus to colon: and the third germ cell type, the mesoderm, develops into connective tissues and coelom, etc.

In the early evolution of an organism, the CNS and ENS may have communicated via chemical signalling. The CNS was predominantly concerned with the external environment (light/heat which changed according to global positioning e.g. day/night/season) and the ENS was concerned more with the food rhythm that may also be integrated with day or night activity depending on the feeding patterns of the organism. Research has progressively shown that the gut and the head brain have many neurotransmitters in common but often having different modes of action. The CNS-ENS linkage to clocks may be fundamental in understanding FGIDs.

\section{CONCLUSION AND DISCUSSION}

Of relevance to this report are those chronobiological features of gastrointestinal function that may lead to the prevention or alleviation of sufferers from IBS and related spectra of disease. It is known, for example, that there is a circadian rhythm in motility $[177,178]$ and that perturbations in this circadian rhythm are likely to cause changes in motility, such as shift-work (and patterns), airtravel (jet lag), and gastrointestinal health problems [179181 ] because there may be desynchronisation of $c 24 \mathrm{~h}$-organ clocks and maladjustment to otherwise optimally phased and functionally integrated clocks such as those existing in the small and large intestine. Organ clocks, apart from clinical definitions and an IBS code, may be just one reason why point prevalence data is difficult to estimate [182, 183].

It is recognised that IBS is probably a wide spectrum of diseases and evidence from families and twin studies indicate that, compared to healthy individuals, FGIDs occur in clusters rather than randomly in the population [184] and concordance is greater in monozygotic twins [185]. This report indicates that a number of hereditary factors may result in FGIDs which may have relatively changed organ clocks, leading to abnormal hormonal and neurotransmitter secretions or polymorphic receptor mechanisms, sensory differences, immunological-epithelial abnormalities in the mucosa, or even the possibility of changes in neural health 
arising from a higher omega-6/omega-3 ratio in cell membranes and ensuing G-protein mechanisms that affect the permeability of the cell to healthy nutrients [186].

In summary this report has attempted to reveal, understand (through considerations of variability) and integrate an array of chronobiological, evolutionary, genetic, biochemical, and clinical knowledge that, if systematically addressed, may lead to components in the disease spectrum of IBS and related clinical problems being effectively treated. Clearly, a task force is needed to accomplish much of the research needed in preventing or treating IBS and related diseases.

\section{CONFLICTS OF INTEREST}

None declared.

\section{ACKNOWLEDGEMENTS}

The authors express gratitude to the Wolfson Research Institute for use of their facilities. DWW is grateful for support on cell-simulation (in yesteryear) from Professor Charles Donaghey, formerly Dept. Industrial Engineering, University of Houston, Texas. Suzanne Sanders, School of Medicine and Health, Durham University, gave valuable support in the preparation of this manuscript.

\section{REFERENCES}

[1] Hungin APS, Whorwell PJ, Tack J, Mearin F. The prevalence, patterns and impact of irritable bowel syndrome: an international survey of 40,000 subjects. Aliment Pharmacol Ther 2003; 17(5): 643-50.

[2] Drossman DA. The Functional Gastrointestinal Disorders and the Rome III Process. Gastroenterology 2006; 130: 1377-90.

[3] Drossman DA, Corazziari E, Delvaux M, et al. (Eds): Rome III: The Functional Gastrointestinal Disorders, 3rd edition. Degnon Associates, Inc., McLean, Virginia, 2006; pp. 963-90.

[4] Corazziari E. Definition and epidemiology of functional gastrointestinal disorders. Best Pract Res Clin Gastroenterol 2004; 18(4): 613-31.

[5] Drossman DA, Thompson WG, Talley NJ, Funch-Jensen P, Janssens J, Whitehead WE. Identification of subgroups of functional gastrointestinal disorders. Gastroenterol Int 1990; 3: 159-72.

[6] Powell R. On certain painfull afflictions of the intestinal canal. Med Trans R Coll Phys 1818; 6: 106-1017.

[7] Engel GI. The need for a new medical model: a challenge for biomedicine. Science 1977; 196: 129-36.

[8] Drossman DA. Presidential address. Gastrointestinal illness and the Biopsychosocial model. Psychosom Med 1998; 60: 258-67.

[9] Hall NJ, Rubin GP, Dougall A, Hungin APS, Neely J. The fight for 'health-related normality': a qualitative study on the experiences of individuals living with established inflammatory bowel disease (IBD). J Health Psychol 2005; 10(3): 443-55.

[10] Singh RB, De Meester F, Wilkzynska A, Wilson DW, Hungin APS. The gut-brain and heart connection. World Heart J 2010 [in press].

[11] Roy CS, Sherrington CS. On the Regulation of the Blood-supply of the Brain. J Physiol 1890; 11(1-2): 85-108.

[12] Laureys S, Boly M, Tononi G. Functional Neuroimaging In: The Neurology of Consciousness: Cognitive Neuroscience and Neuropathology. Laureys S, Tononi G, Eds. Academic PressElsevier 2009; pp. 31-42.

[13] Mayer EA, Gebhart GF. Basic and clinical aspects of visceral hyperalgesia. Gastroenterology 1994; 107: 271-93.

[14] Sheehan J, Gaman A, Vangel M, Kuo B. Pooled analysis of brain activity in irritable bowel syndrome and controls during rectal balloon distension. Neurogastroenterology and Motility 2011; 23(4): 336-58.

[15] Johnson AC, Myers B, Lazovic J, Towner R, Greenwood-Van Meerveld B. Brain Activation in Response to Visceral Stimulation in Rats with Amygdala Implants of Corticosterone: An fMRI Study. Plos One 2010; 5 (1): e8573.

[16] Hom CC. Electrophysiology of vagal afferents: amino acid detection in the gut. Ann NYAcad Sci 2009; 1170: 69-76.

[17] Clarke G, Fitzgerald P, Hennessy AA, et al. Marked elevations in pro-inflammatory polyunsaturated fatty acid metabolites in females with irritable bowel syndrome. J Lipid Res 2010; 51(5): 1186-92.

[18] Thompson WG. The road to Rome. Gut 1999; 45(11): II80-II81.

[19] Zeman M, Cornélissen G, Balazova K, et al. Circadian rhythm of melatonin in rat duodenum. In: Cornélissen G, Kenner R, Fiser B, Siegelova J, eds. Proceedings Symposium: Chronobiology in Medicine. Brno: Masaryk University; 2004; pp. 95-97.

[20] Skelton P. Evolution: a biological and palaeontological approach. Wokingham, Addison-Wesley Publishing Company 1993; 1064.

[21] Barnes J. The Presocratic Philosophers Revised Eds, Routledge 1982; pp. 501

[22] Crick F. The astonishing hypothesis: the scientific search for the soul.1994; New York, Charles Scribner's Sons.

[23] Nurse P. Biology in the 21st Century. Society of Biology Address, Search "Society Biology Nurse" 2010, Sir PaulNurse-remarks-25 March 2010.pdf.

[24] Kandel ER. A new intellectual framework for psychiatry. Am J Psychiatry 1998; 155: 457-69.

[25] Blagosklonny MV, Pardee AB. Conceptual biology: unearthing the gems. Nature 2002; 416: 373.

[26] Rossi EL, Rossi KL. Open questions on mind, genes, consciousness, and behaviour: the circadian and ultradian rhythms of art, beauty, and truth in creativity. In: Eds. D. Lloyd \& Rossi E, Ultradian Rhythms from molecules to mind: a new version of life.2008; Springer Science + Business Media B.V. Berlin.

[27] Zijdenbos IL, de Wit NJ, van der Heijden GJ, Rubin G, Quartero AO. Psychological treatments for the management of irritable bowel syndrome. Cochrane Database Syst Rev 2009; 1: CD006442.

[28] Azpiroz F, Bouin M, Camilleri M, et al. Mechanisms of hypersensitivity in IBS and functional disorders. Neurogastroenterol Motil 2007; 19: 62-88.

[29] Segal E, Sirlin C, Ooi C, et al. Decoding global gene expression programs in liver cancer by noninvasive imaging. Nature Biotechnol 2007; 25: 675-80.

[30] Rossi E, Iannotti S, Cozzolino M, Castiglione S, Cicatelli A, Rossi K. A Pilot Study of Positive Expectations and Focused Attention via a New Protocol for Optimizing Therapeutic Hypnosis and Psychotherapy assessed with DNA Microarrays: The Creative Psychosocial Genomic Healing Experience. Sleep Hypn 2008; 10(2): 39-44.

[31] Lamb J, Crawford E, Peck D, et al. The connectivity map: Using gene-expression signatures to connect small molecules, genes and diease. Science 2006; 313: 1929-35.

[32] Smith K. Treatment frontiers. Nature 2010; 466: S15-8.

[33] Yamamoto T, Nakahata Y, Soma H, Akashi M, Mamine T, Takumi T. Transcriptional oscillation of canonical clock genes in mouse peripheral tissues. BMC Mol Biol 2004; 5 : 18.

[34] Siepka SM, Yoo SH, Park J, et al. Circadian mutant Overtime reveals F-box protein FBXL3 regulation of cryptochrome and period gene expression. Cell 2007; 129(5): 1011-23.

[35] Arendt J, Wetterberg L, Heyden T, Sizonenko PC, Paunier L. Radioimmunoassay of Melatonin: Human Serum and Cerebrospinal Fluid. Horm Res 1977; 8: 65-75.

[36] Bubenik GA, Pang SF, Hacker RR, Smith PS. Melatonin concentrations in serum and tissues of porcine gastrointestinal tract and their relationship to the intake and passage of food. J Pineal Res 1996; 21(4): 251-6.

[37] Balsalobre A. Clock genes in mammalian peripheral tissues. Cell Tissue Res 2002; 309: 193-9.

[38] Schibler U, Ripperger J, Brown SA. Peripheral circadian oscillators in mammals: time and food. J Biol Rhythms 2003; 18: 250-60. 
[39] James FO, Bolvin DB, Charbonneau S, Belanger V, Cermakian, $\mathrm{N}$. Expression of clock genes in human peripheral blood mononuclear cells throughout the sleep/wake and circadian cycles. Chronobiol Int 2007; 24(6): 1009-34.

[40] Scott JR, Hellmich HL, Hoogerwerf WA. Circadian expression of clock genes in the murine colon. Gastroenterology 2008; 128(Suppl 2): A1500.

[41] Hoogenwerf WA, Hellmich HL, Cornélissen G, et al. Clock gene expression in the murine gastrointestinal tract: endogenous rhythmicity and effects of a feeding regimen. Gastroenterology 2007; 133(4): 1373-6.

[42] Garaulet M, Madrid JA. Chronobiological aspects of nutrition, metabolic syndrome and obesity. Adv Drug Deliv Rev 2010. [In Press].

[43] Abe M, Herzog ED, Yamazaki S, et al. Circadian rhythms in isolated brain regions. J Neurosci 2002; 22: 350-6.

[44] Bjarnason GA, Jordan RCK, Sothern R. Circadian Variation in the Expression of Cell-Cycle Proteins in Human Oral Epithelium. Amer J Pathol 1999; 154(2): 613-22.

[45] Nurse PM. Nobel Lecture. Cyclin dependent kinases and cell cycle control. Bioscience Reports 2002; 22(5-6): 487-99.

[46] Singh RB, Niaz MA, Cornélissen G, et al. Circadian rhythmicity of circulating vitamin concentration. Scripta Medica (Brno) 2001; 74: 93-96.

[47] Singh RB, Weydahl A, Otsuka K, et al. Can nutrition influence circadian rhythm and heart rate variability? Biomed Pharmecother J 2001; 55: 115-24.

[48] Singh RB, Gupta A, Pella D, Kumar A. Circadian Cardiology. World Heart J 2008; 1: 101-25.

[49] Unsal-Kamaz K, Mullen TE, Kaufmann WK, Sancar A. Coupling of human circadian and cell cycles by the Timelss Protein. Mol Cell Biol 2005; 25(8): 3109-16.

[50] Brillat-Savarin JA. Physiologie du goût, ou, méditations de gastonomie transcendente. Ouvrage theorique, historique et à l'ordre du jour, dedié aux gastronomes parisiens. A Soutelet \& Co., Paris, Vol. I, 1826; 390PP, Vol II, pp. 442.

[51] Halberg F, Haus E, Cornélissen G. From biologic rhythms to chronomes relevant for nutrition. In: Marriott, B.M. (Ed): Not eating enough: overcoming underconsumption of military operational rations. National Academy Press, 1995; pp. 361-72.

[52] Caruso CC, Lusk SL, Gillespie B.W. Relationship of work schedules to gastrointestinal diagnoses, symptoms, and medication use in auto factory workers. Am J Ind Med 2004; 46: 586-98.

[53] Scott AJ. Shift work and health. Prim Care 2000; 27: 1057-79.

[54] Waterhouse J, Buckley P, Edwards B, Reilly T. Differences in Eating Habits Between Night and Day Workers. Chronobiol Int 2003; 20(6): 1075-92.

[55] Lu WZ, Gwee KA, Ho KY. Functional bowel disorders in rotating shift nurses may be related to sleep disturbances. Eur $\mathbf{J}$ Gastroenterol Hepatol 2006; 18: 623-7.

[56] Nojkov BRJ, Hoogerwerf S, Chey WD. The effect of shift work on the prevalence and clinical impact of functional bowel disorders in nurses. Am J Gastroenterol 2008; 103: S469.

[57] Scheving LE, Burns ER, Pauly JE Tsai T-H. Circadian variation in cell division of the mouse alimentary tract, bone marrow and corneal epithelium. Anat Rec 1978; 191: 479-86.

[58] Scheving LE, Scheving LA, Tsai T-H, Pauly JE. Effect of fasting on circadian rhythmicity in deoxyribonucleic acid synthesis of several murine tissues. J Nutr 1984; 114: 2160-6.

[59] Rubin NH, Hokanson JA, Mayschak JW, Tsai T-H., Barranco SC, Scheving LE. Several cytokinetic methods for showing circadian variation in normal murine tissue and in a tumor. Am J Anat 1983; 168(1): 15-26.

[60] Quastler H, Sherman FG. Cell population kinetics in the intestinal epithelium of the mouse. Exp Cell Res 1959; 17(3): 420-38.

[61] Donaghey C. CELLSIM H User's Manual. Department of Industrial Engineering, 1975; University of Houston, Houston, TX.

[62] Donaghey C, Drewinko BA. Computer Simulation Program for the Study of Cellular Growth Kinetics and its Application to the Analysis of Human Lymphoma Cells in Vitro. Comput Biomed Res 1975; 8: 118-28.
[63] Donaghey C, Barlogie B, Stubblefield E. Simulating Flow Microfluorometry Experiments With the Computer Language CELLSIM. BioSystems 1978; 10: 339-47.

[64] Wilson DW, Griffiths K. Advances in research: simulation of cell cycles. In: Cardiff Joint Computer Centre-Report. 1977; Cardiff, Cardiff University.

[65] Cornélissen G, Kanabrocki E, Halberg J, Halberg F. Toward the chronobiology and chronomics of the intestine. In: Zabielski $\mathrm{R}$, Gregory PC, Westrom B, editors. Biology of the Intestine in Growing Animals.2002; pp. 751-804, Amsterdam: Elsevier NV.

[66] Drossman DA, Chairmen WTC. The functional gastrointestinal disorders and their diagnosis: a coming of age. In: D.A. Drossman (ed.). The functional gastrointestinal disorders, diagnosis, pathophysiology, and treatment. Boston: Little, Brown and Company, 1994; pp. 1-23.

[67] Selye HA Syndrome produced by diverse nocuous agents. Nature 1936; 138: 32.

[68] Vilcek J. The cytokines: an overview. In: A. Thompson, Editor, The Cytokine Handbook 3rd ed., Academic Press, San Diego, 1998; pp. 1-20

[69] Bayliss W, Starling EH. The mechanism of pancreatic secretion. J Physiol (London) 1902; 28: 325-53.

[70] Linnaeus C, Tomus I. Systema naturae per regna tria naturae, secundum classes, ordines, genera, species, cum characteribus, differentiis, synonymis, locis. Editio decima, reformata. Holmiae. (Laurentii Salvii).1758: (1-4), 1-824.

[71] Passamaneck YJ, Di Gregorio A. Ciona intestinalis: chordate development made simple. Dev Dyn 2005; 233(1): 1-19.

[72] Snoek SA, Borensztajn KS, van den Wijngaard RM, de Jonge WJ. Neuropeptide Receptors in Intestinal Disease: Physiology and Therapeutic Potential. Current Pharmaceutical Design 2010; 16(9): 1091-105.

[73] Snoek SA. Verstege MI. Boeckxstaens GE. van den Wijngaard RM. de Jonge WJ. The enteric nervous system as a regulator of intestinal epithelial barrier function in health and disease. Expert rev gastroenterol hepatol 2010; 4(5): 637-51.

[74] Inui A, Asakawa A, Bowers CY, et al. Ghrelin, appetite, and gastric motility: the emerging role of the stomach as an endocrine organ. FASEB J 2004; 18: 439-56.

[75] Page A, Slattery J, Milte C, et al. Ghrelin selectively reduces mechanosensitivity of upper gastrointestinal vagal afferents. Am J Physiol Gastrointest Liver Physiol 2007; 292 (5): 1376-84.

[76] Wren AM, Small CJ, Ward HL, et al. The Novel Hypothalamic Peptide Ghrelin Stimulates Food Intake and Growth Hormone Secretion. Endocrinology 2000; 141(11): 4325-8.

[77] Perboni S, Inui A. Appetite and gastrointestinal motility: role of ghrelin-family peptides. Clin Nutr 2010; 29(2): 227-34.

[78] Andrews PLR, Sanger GJ. Abdominal vagal afferent neurones: an important target for the treatment of gastrointestinal dysfunction. Curr Opin Pharmacol 2002; 2(6): 650-56.

[79] Semnani S, Roshandel G, Keshtkar A, et al. Serum leptin levels and irritable bowel syndrome: a new hypothesis. J Clinical Gastroenterol 2009; 43(9): 826-30.

[80] Zhang HJ, Yan Y, Shi RH, Lin Z, Wang MF, Lin L. Correlation of Gut Hormones with Irritable Bowel Syndrome. Digestion 2008; 78: 72-6.

[81] Halberg F, Cornélissen G, Conti A, et al. The pineal gland and chronobiologic history: mind and spirit as feedsidewards in time structures for prehabilitation. In: Bartsch C, Bartsch H, Blask DE, Cardinali DP, Hrushesky WJM, Mecke W, editors. The Pineal Gland and Cancer: Neuroimmunoendocrine Mechanisms in Malignancy. Heidelberg: Springer; 2001; p. 66-116.

[82] Mayakawa MT, DiStephano JJ III, Swerdloff RS. A dynamic system model of testosterone transport and metabolism in normal man. Ann Biomed Eng 1974; 2: 307-20.

[83] Bucinskaite V, Tolessa T, Pedersen J, et al. Receptor-mediated activation of gastric vagal afferents by glucagon-like peptide- 1 in the rat. Neurogastroenterol Motil 2009; 21: 978-78.

[84] Hellstrom PM. Glp-1 playing the role of a gut regulatory compound. Acta Physiologica 2011; 201: 151-6. 
[85] Thaler JP, Cummings DF. Metabolism: food alert. Nature 2008; 452: 941-2.

[86] Wang PY, Caspi L, Lam CK, et al. Upper intestinal lipids trigger a gut-brain-liver axis to regulate glucose production. Nature 2008; 452: 1012-16.

[87] Sakurai T, Amemiya A, Ishii M, et al. Orexins and orexin receptors: a family of hypothalamic neuropeptides and $\mathrm{G}$ proteincoupled receptors that regulate feeding behavior. Cell 1998; 92: 573-85.

[88] Ohno K, Sakurai T. Orexin neuronal circuitry: role in the regulation of sleep and wakefulness. Neuroendocrinol 2008; 29: 70-87.

[89] de Lecea L, Kilduff TS, Peyron C, et al. The hypocretins: hypothalamus-specific peptides with neuroexcitatory activity. PNAS 1998; 95(1): 322-7.

[90] Ohumura T, Takakusaki K. Role of orexin in central regulation of gastrointestinal functions. J Gastroenterol 2008; 43: 652-60.

[91] Takahashi N, Okumura T, Yamada H, Kohgo Y. Stimulation of gastric acid secretion by centrally administered orexin-A in conscious rats. Biochem Biophys Res Commun 1999; 254: 623-7.

[92] Löckinger A, Koeberle D, St. Koenig P, et al. Neuropeptide chronomics in clinically healthy young adults: circaoctohoran and circadian patterns. Peptides 2004; 25: 533-42.

[93] Halberg F, Carandente F, Cornélissen G, Katinas GS. Glossary of chronobiology. Chronobiologia 1977; 4(Suppl 1): 1-189.

[94] Camilleri M, Carlson P, Zinsmeister AR, et al. Neuropeptide S receptor induces neuropeptide expression and associates with intermediate phenotypes of Functional Gastrointestinal disorders. Gastroenterology 2010; 138(1): 98-107.

[95] Esposito K, Marfella R, Ciotola M, Di Palo C, Guigliano G, Marfella R. Effect of a Mediterranean style diet on endothelial dysfunction and markers of vascular inflammation in the metabolic syndrome: a randomized trial. JAMA 2004; 292: 1440-6.

[96] Singh RB, Otsuka K, Chiang CE, Joshi SR. Nutritional predictors and modulators of metabolic syndrome. J Nutr Environ Med 2004; 14: 3-16.

[97] Dai J, Miller AH, Bremner JD, Goldberg J, Jones L, Shallenberger L. Adherence to the Mediterranean diet is inversely associated with circulating interleukin-6 among middle-aged men. A Twin Study. Circulation 2008; 117: 169-75.

[98] Kwiatek AW, Singh RB, De Meester F. Nutrition and behaviour: the role of w-3 fatty acids. Open Nutra J 2010; 3: 119-28.

[99] Singh RB, de Meester F, Wilczynska A, Wilson DW, Hungin APS. The Liver-Pancreas and the brain connection in the pathogenesis of obesity and metabolic syndrome 2010; Nova Publishers [In Press].

[100] Dubnov G, Pella D, Singh RB. The effect of an alpha-linolenic acid rich diet on the circadian rhythm of cardiac events. World Heart J 2008; 1: 49-56.

[101] Eaton SB, Eaton SB III, Sinclair AJ, Cordain L, Mann NJ. Dietary intake of long chain polyunsaturated fatty acids during the Paleolithic. World Rev Nutr Diet 1998; 83: 12-23.

[102] De Meester F. Progress in lipid nutrition. In: Simopoulos AP, De Meester F (eds), A Balanced Omega-6/Omega-3 Fatty acid Ratio. Cholesterol and Coronary Heart Disease. World Rev Nutr Diet Basel 2009; 100: 110-21.

[103] Wilczynska A, De Meester F, Singh RB, Pella D. Between body and mind. Dietary and environmental influence on mental function and health. Psychological Institute, University of Silesia, Partner Center for Training, Gliwice, Poland. 2009 [http://www.tsimtsoum.net/ publicevents/14th\%20WCCN\%20-\%20Editorial\%20TsimTsoum.pdf].

[104] Singh RB, de Meester F, Wilczynska A. The Tsim Tsoum Approaches for Prevention of Cardiovascular Disease. Cardiology Research and Practice 2010. [In Press].

[105] Lerner AB, Case JD, Takahashi Y, Lee TH, Mori W. Isolation of melatonin, the pineal gland factor that lightens melanocytes. J Amer Chem Soc 1958; 80: 2587.

[106] Lerner AB, Case JD, Heinzelman RU. Structure of melatonin. J Am Chem Soc 1959; 81: 6084-5.

[107] Vakkuri O, Rintamaki H, Leppaluoto J. Presence of immunoreactive melatonin in different tissues of the pigeon (Columba livia). Gen Comp Endocrinol 1985; 58: 69-75.
[108] Saha L, Malhotra S, Rana S, Bhasin D, Pandhi P. A preliminary study of melatonin in irritable bowel syndrome. $\mathrm{J}$ Clin Gastroenterol 2007; 41(1): 29-32.

[109] Descartes, R. Les passions d'ame. In: Descartes (1824). Oeuvres de Descartes. Volume 4, 1649 Victor Cousin, Paris.

[110] Descartes R. Traite de l'homme (Treatis of Man, Hall, T.S., trans.) 1972; Harvard University Press, Cambridge, Mass, USA.

[111] Rapport MM, Green AA, Page IH. Serum vasoconstrictor, serotonin; isolation and characterization. J Biol Chem 1948; 176(3): 1243-51.

[112] Song GH, Leng PH, Gwee KA, Moochhala SM Ho KY. Melatonin improves abdominal pain in irritable bowel syndrome patients who have sleep disturbances: a randomized, double blind, placebo controlled study. Gut 2005; 54(10): 1353-4.

[113] Pang SF, Shiu SYW, Tse SF. Effect of photic manipulation on the level of melatonin in the retinas of frogs (Rana tigrina regulosa). Gen Comp Endocrinol 1985; 58(3): 464-70.

[114] Manchester LC, Tan DX, Reiter RJ, Park W, Monis K, Qi W. High levels of melatonin in the seeds of edible plants: possible function in germ tissue protection. Life Sci 2000; 67: 3023-9.

[115] Martin MT, Azpiroz F, Malagelada JR. Melatonin and the gastrointestinal tract. Therapie 1998; 53: 453-8.

[116] Maldonado MD, Moreno H, Calvo JR. Melatonin present in beer contributes to increase the levels of melatonin and antioxidant capacity of the human serum. Clin Nutr 2009; 28(2): 188-91.

[117] Illnerova H, Buresova M, Presl J. Melatonin rhythm in human milk. J Clin Endocrinol Metab 1993; 77: 838-41.

[118] Cubero J, Valero V, Sanchez J, et al. The circadian rhythm of tryptophan in breast milk affects the rhythms of 6sulfatoxymelatonin and sleep in newborn. Neuroendocrinol Lett 2005; 26(6): 657-61.

[119] Bradbury RB, White DE. Oestrogens and related substances in plants. Vitam Horm 1954; 12: 207-233.

[120] Van Tassel DL, Li J, O'Neill SD. Melatonin: identification of a potential dark signal in plants. Plant Physiol 1993; 102(Supplement 1): 659.

[121] Van Tassel DL, Roberts NJ, O'Neill SD. Melatonin from higher plants: isolation and identification of $\mathrm{N}$-acetyl-5-methoxytryptamine. Plant Physiol 1995; 108: 101.

[122] Van Tassel DL, Roberts N, Lewy A, O'Neill SD. Melatonin in plant organs. JPR 2001; 31: 8-15.

[123] Kolár J, Machácková I. Melatonin: does it regulate rhythmicity and photoperiodism also in higher plants? Flower Newslett 1994; 17: 53-4.

[124] Kolár J, Machácková I, Illnerová H, Prinsen E, Van Dongen W, Van Onckelen HA. Melatonin in higher plants determined by radioimmunoassay and liquid chromatography-mass spectometry. Biol Rhythm Res 1995; 26: 406.

[125] Dubbels R, Reiter RJ, Klenke E, et al. Melatonin in edible plants identified by radioimmunoassay and by high performance liquid chromatography-mass spectrometry. JPR 1995; 18: 28-31.

[126] Hattori A, Migitaka H, Iigo M, et al. Identification of melatonin in plants and its effects on plasma melatonin levels and binding to melatonin receptors in vertebrates. Biochem Mol Biol Int 1995; 35: 627-34.

[127] Reiter RJ, Tan DX, Manchester LC, et al. Melatonin in edible plants (phytomelatonin): identification, concentrations, bioavailability and proposed functions. World Rev Nutr Diet 2007; 97: 211-30.

[128] Badria FA. Melatonin, serotonin, and tryptamine in some Egyptian food and medicinal plants. J Med Food 2002; 5:153-7.

[129] Hardeland R, Reiter RJ, Poeggeler B, Tan DX. The significance of the metabolism of the neurohormone melatonin: antioxidative protection and formation of bioactive substances. Neurosci Biobehav Rev 1993; 17: 347-57.

[130] Tan DX, Reiter RJ, Manchester LC, et al. Chemical and physical properties and potential mechanisms: melatonin as a broad spectrum antioxidant and free radical scavenger. Curr Top Med Chem 2002; 2: 181-97.

[131] Kolár J, Machácková I, Eder J, et al. Melatonin: occurrence and daily rhythm in Chenopodium rubrum. Phytochemistry 1997; 44: 1407-13. 
[132] Kolár J, Machácková I. Melatonin in higher plants: occurrence and possible functions. JPR 2005; 39: 333-41.

[133] Wolf K, Kolár J, Witters E, van Dongen W, van Onckelen H, Machácková I. Daily profile of melatonin levels in Chenopodium rubrum L. depends on photoperiod. J Plant Physiol 2001; 158: 1491-3.

[134] Lei XY, Zhu RY, Zhang GY, Dai YR. Attenuation of cold-induced apoptosis by exogenous melatonin in carrot suspension cells: the possible involvement of polyamines. JPR 2004; 36: 126-31.

[135] Manchester LC, Poeggeler B, Alvares FL, Ogden GB, Reiter RJ. Melatonin immunoreactivity in the photosynthetic prokaryote Rhodospirillum rubrum: implications for an ancient antioxidant system. Cell Mol Biol Res 1995; 41: 391-5.

[136] Hardeland R, Poeggeler B. Non-vertebrate melatonin. JPR 2003; 34: 233-41.

[137] Tan DX, Manchester LC, Di Mascio P, Martinez GR, Prado FM, Reiter RJ. Novel rhythms of N1-acetyl-N2-formyl-5methoxykynuramine and its precursor melatonin in water hyacinth: importance for phytoremediation. The FASEB J 2007; 21: 1724-9.

[138] Tan DX, Manchester LC, Helton P, Reiter RJ. Phytoremediative capacity of plants enriched with melatonin. Plant Signal Behav 2007; 2: 514-6.

[139] Hoogerwerf WA, Scott JR, Savidge TC, Hellmich H. Timed feeding alters clock gene expression in the murine stomach and colon. Gastroenterology 2006; 130(Suppl 2): A456.

[140] Panda S, Sato TK, Castrucci AM, et al. Melanopsin (Opn4) requirement for normal light-induced circadian phase shifting. Science 2002; 298: 2213-6.

[141] Liu AC, Lewis WG, Kay SA. Mammalian circadian signalling networks and therapeutic targets. Nat Chem Biol 2007; 3: 630-9.

[142] Hannibal J. Neurotransmitters of the retino-hypothalamic tract. Cell Tissue Res 2002; 309: 73-88.

[143] Albrecht U, Sun ZS, Eichele G, Lee CC. A differential response of two putative mammalian circadian regulators, mper1 and mper2, to light. Cell 1997; 91: 1055-64.

[144] Yan L, Silver R. Differential induction and localization of mPer1 and mPer2 during advancing and delaying phase shifts. Eur $\mathbf{J}$ Neurosci 2002; 16: 1531-40.

[145] Kalsbeek A, Palm IF, La Fleur SE, et al. SCN outputs and the hypothalamic balance of life. J Biol Rhythms 2006; 21: 458-69.

[146] Albrecht U. Circadian clocks in mood-related behaviors. Ann Med 2010 6; 42(4): 241-51.

[147] Huang T, Nei C, Su W, The Yellow Emporer's classic of internal medicine. (Veith, I., trans).1949. University of California Press, Berkeleey.

[148] Klein DC, Namboodiri MAA, Auerbach DA. The melatonin rhythm generating system: developmental aspects. Life Sci 1981; 28: $1975-86$

[149] Murch SJ, Krishna Raj S, Saxena PK. Tryptophan is a precursor for melatonin and serotonin biosynthesis in in vitro regenerated $\mathrm{St}$ John's wort (Hypericum perforatum L. cv. Anthos) plants. Plant Cell Rep 2000; 19: 698-704.

[150] Afreen F, Zobayed SM, Kozai T. Melatonin in Glycyrrhiza uralensis: response of plant roots to spectral quality of light and UV-B radiation. JPR 2006; 41: 108-115.

[151] Klein DC, Coon SL, Roseboom PH, et al. The melatonin rhythmgenerating enzyme: molecular regulation of serotonin $\mathrm{N}$ acetyltransferase in the pineal gland. Recent Prog Horm Res 1997; 52: 307-57.

[152] Raikhlin NT, Kvetnoy IM. Melatonin and enterochromaffine cells. Acta Histochem 1976; 55: 19-24.

[153] Huether G, Poegeller G, Reimer R, George A. Effect of tryptophan administration on circulating melatonin levels in chicks and rats: evidence for stimulation of melatonin synthesis and release in the gastrointestinal tract. Life Sci 1992; 51: 945-53.

[154] Thor PJ, Krolczyk G, Gil K, Zurowski D, Nowak L. Melatonin and serotonin effects on gastrointestinal motility. J Physiol Pharmacol 2007; 58: 97-105.

[155] Pearse AG. The cytochemistry and ultrastructure of polypeptide hormone-producing cells of the APUD series and the embryologic, physiologic and pathologic implications of the concept. J Histochem Cytochem 1969; 17(5): 303-13.
[156] Langton P, Ward SM, Carl A, Norrel MA, Sanders KM. Spontaneous electrical activity of interstitial cells of Cajal isolated from canine proximal colon. Proc Natl Acad Sci USA 1989; 86: $7280-4$.

[157] Mantovani M, Kaster MP, Pertile R, Calixto JB, Rodrigues AL, Santos AR. Mechanisms involved in the antinociception caused by melatonin in mice. JPR 2006; 41: 382-9.

[158] Lu WZ, Gwee KA, Moochhalla S, Ho KY. Melatonin improves bowel symptoms in female patients with irritable bowel syndrome: a double-blind placebo-controlled study. Aliment Pharmacol Ther 2005; 22: 927-34.

[159] Konturek SJ, Pepara J, Zabielski K, et al. Brain-gut axis in pancreatic secretion and appetite control. J Physiol Pharmacol 2003; 54: 293-317.

[160] Chazot G, Claustrat B, Brun J, Jordan D, Sassolas G, Schott BA. Chronobiological study of melatonin, cortisol growth hormone and prolactin secretion in cluster headache. Cephalalgia; 1984; 4: 213 20.

[161] Mozaffari S, Rahimi R, Abdollahi M. Implications of Melatonin Therapy in Irritable Bowel Syndrome: A Systematic Review. Curr Pharm Des 2010; 16(33): 3646-55.

[162] Jones J, Boorman J, Cann P, et al. British Society of Gastroenterology guidelines for the management of the irritable bowel syndrome. GUT 2000; 47: ii1-ii19.

[163] Eckburg PB, Bik EM, Bernstein CN, et al. Diversity of the human intestinal microbial flora. Science 2005; 308(5728): 1635-8.

[164] Parkes GC, Brostoff J, Whelan K, Sanderson JD. Gastrointestinal microbiota in irritable bowel syndrome: their role in its pathogenesis and treatment. Am J Gastroenterol 2008; 103: 155767.

[165] Hoogenwerf WA. Biologic Clocks and the Gut. Curr Gastroenterol Rep 2006; 8: 353-59.

[166] McConnell EL, Short MD, Basit AW. An in vivo comparison of intestinal $\mathrm{pH}$ and bacteria as physiological trigger mechanisms for colonic targeting in man. J Control Release 2008; 130: 154-60.

[167] Mills DJ, Tuchy KM, Booth J, et al. Dietary glycated protein modulates the colonic microbiota towards a more detrimental composition in ulcerative colitus patients and in non-ulcerative colitus subjects. J Appl Microbiol 2008; 105(3): 706-14.

[168] Simon GL, Gorbach SL. Intestinal flora in health and disease. Gastroenterology 1984; 86(1): 174-93

[169] Bernhardt H, Knoke M. Mycological aspects of gastrointestinal microflora, Scand. J Gastroent 1997; 32: 102-6.

[170] Gilad Y, Oshlack A, Smyth GK, Speed TP, White KP. Expresion profiling in primates reveals a rapid evolution of human transcription factors. Nature 2006; 440: 242-5.

[171] Hawks L, Wang ET, Cochran GM. Harpending HC, Moyzis RK. Recent acceleration of human adaptive evolution. Proc Natl Acad Sci USA 2007; 104: 20753-8.

[172] Taub E, Cuevas JL, Cook EW, Cromwell M, Whitehead WE. Irritable bowel syndrome defined by factor analysis. Gender and race comparisons. Dig Dis Sci 1995; 40(12): 2647-55.

[173] Vernia P, Ricciardi MR, Frandin AC, Bilotta T, Frieri G. Lactose malabsorption and irritable bowel syndrome. Effect of a long-term lactose-free diet. Ital J Gastroenterol 1995; 27(3): 117-21.

[174] Gwee KA. Irritable bowel syndrome in developing countries-a disorder of civilization or colonization? Neurogastroenterol Motil 2005; 17: 317-24.

[175] Aon MA, Roussel MR, Cortassa S, et al. The Scale-Free Dynamics of Eukaryotic Cells. PLoS ONE 2008; 3(11): e3624.

[176] Brauckmann S, Gilbert SF. Sucking in the Gut: A Brief History of Early Studies on Gastrulation. In Stern C, ed. Gastrulation: From Cells to Embryo. 2004; Cold Spring Harbor, NY: Cold Spring Harbor Laboratory Press.

[177] Auwerda JJ, Bac DJ, Schouten WR. Circadian rhythm of rectal motor complexes. Dis Colon Rectum 2001; 44: 1328-32.

[178] Frexinos J, Bueno L, Fioramonti J. Diurnal changes in myoelectric spiking activity of the human colon. Gastroenterology 1985; 88: 1104-10.

[179] Vener KJ, Szabo S, Moore JG. The effect of shift work on gastrointestinal (GI) function: a review. Chronobiologia 1985; 16: 421-39. 
[180] Costa G. The impact of shift and night work on health. Appl Ergon 1996; 27: 9-16

[181] Knutsson A. Health disorders of shift workers. Occup Med (Lond) 2003; 53: 103-8.

[182] Kay L, Jorgensen T, Jensen TH. The epidemiology of irritable bowel syndrome in a random population: prevalence, incidence, natural history and risk factors. J Intern Med 1994; 236: 23-30.

[183] Talley N J, O'Keefe EA, Zinsmeister AR, Melton LJ III. Prevalence of gastrointestinal syptoms in the elderly: a populationbased study. Gastroenterology 1992; 102: 895-901.
[184] Morris-Yates A, Talley NJ, Boyce PM, Nandurkar S, Andrews G. Evidence of a genetic contribution to functional bowel disorder. Am J Gastroenterol 1998; 93: 1311-7.

[185] Levy RL, Jones KR, Whitehead WE, Feld SI, Talley NJ, Corey LA. Irritable bowel syndrome in twins: heredity and social learning both contribute to etiology. Gastroenterology 2001; 121: 799-804.

[186] Simopoulos AP. Evolutionary aspects of the dietary omega6:omega-3 fatty acid ratio: medical implications. In: Simopouos AP, De Meester F. 2009, Karger, London.

(C) Wilson et al.; Licensee Bentham Open.

This is an open access article licensed under the terms of the Creative Commons Attribution Non-Commercial License (http://creativecommons. org/licenses/ by-nc/3. 0/) which permits unrestricted, non-commercial use, distribution and reproduction in any medium, provided the work is properly cited. 